\title{
A heretic with a distorted face: Sophia of Montferrat, the 'other' empress of Byzantium
}

\author{
Petra Melichar \\ Department of Paleoslavonic and Byzantine Studies, \\ Slavonic Institute of the Czech Academy of Sciences, \\ Czech Republic, melichar@slu.cas.cz
}

\section{Abstract}

Focusing on the idea that even a princess favored by both the senior emperor and the Pope could become an outcast and fail to succeed in her role, the present paper describes the life of Sophia of Montferrat, an Italian noblewoman of Byzantine descent who married John VIII Palaiologos in 1421. The aim of the author is to inquire into Sophia's life and the circumstances which led to her being rejected by her husband and her subjects, preventing her from successfully integrating into Byzantine society.

Keywords: Byzantine empress; Palaiologan period; integration; religious conversion; beauty standards; disability studies 


\title{
Heretic with a Distorted Face: Sophia of Montferrat, the 'Other' Empress of Byzantium*
}

\author{
Petra Melichar \\ Slavonic Institute of the Czech Academy of Sciences, Czech Republic \\ Beautiful' was the most common epithet applied to imperial women \\ Of all ages and roles, excepting only mothers. \\ Barbara Hill ${ }^{1}$
}

\section{Introduction}

The general perception of a female societal outcast is often connected with foreigners, prostitutes, the mentally retarded, or possibly even mediums and spiritists. However, the primary sources reveal that even high-born ladies who had neither committed a crime nor led a shady existence at society's edge could come to be perceived as outsiders. The present paper introduces the story of a crowned empress of Byzantium, Sophia Palaiologina or Sophia of Montferrat (d. 1434), who despite her illustrious descent and the permission of the Pope to marry an Orthodox prince (a boon only rarely bestowed on Catholic princesses), nonetheless failed to integrate into the Byzantine court. The aim of this article is to present the facts of Sophia's life and consider the causes which led to her being rejected by her husband and her people.

\footnotetext{
* The present study was prepared with the financial support of the Grant Agency of the Czech Republic (GAČR) as part of the project Foreign Bride, Negotiator, and Pious Woman: Empresses in Late Byzantium (nr. 14-08304P).

1 Barbara Hill, Imperial Women in Byzantium 1025-1204: Power, Patronage and Ideology (London: Routledge, 1999), 88.
} 


\section{From an unexpected proposal to a runaway wife}

Around the year $1394,{ }^{2}$ a girl was born to the family of Teodoro II Paleologo of Montferrat (d. 1418) and Jeanne de Bar. ${ }^{3}$ In due course, she was baptized Sophia. ${ }^{4}$ On her mother's side, she was connected with the French royal family; through her father, she was a descendant of Byzantine emperors. But in spite of her noble lineage, Sophia seemed marked for misfortune from birth, for her face was severely disfigured. The consequences were devastating from the beginning. In 1405, the princess was engaged to the powerful Prince Philip Visconti, the lord of Milan. ${ }^{5}$ The engagement was subsequently broken by the groom, and Sophia remained unwed.

Quite unexpectedly, fifteen years after her failed first engagement, an eminent embassy arrived at the court of Sophia's brother to request her hand in marriage. The emissaries had come from Byzantium, dispatched by Manuel II Palaiologos (r. 1391-1425), who wished to find a new bride for his successor, John VIII (r. 1425-1448). John's young wife, Anna of Moscow, had died of the plague in 1417. Eager to acquire military allies in the West, the emperor sought brides from great noble houses to marry his sons. In order to facilitate negotiations at the Italian courts, he reopened the dialogue regarding a union between the

\footnotetext{
2 See the argumentation of Malgorzata Dabrowska in Malgorzata Dabrowska, "Sophia de Montferrat or the History of One Face," Acta Universitatis Lodziensis, Folia bistorica 56 (1996): 177-199, 181.

${ }^{3}$ Sophia's mother, Jeanne de Bar, was a member of the high French aristocracy, being the granddaughter of the French king, John II (r. 1350 -1364), and his wife, Bona of Luxembourg (d. 1349).

${ }^{4}$ Erich Trapp, Rainer Walther, Hans-Veit Beyer et al., Prosopographisches Lexikon der Palaiologenzeit, 12 volumes, (further only PLP), Addenda et Indices, (Vienna: Verlag der Österreichischen Akademie der Wissenschaften, 1976-96), n. 26389. For an interesting reconstruction of Sophia's life, see M. Dabrowska, "Sophia de Montferrat"; Donald M. Nicol, The Last Centuries of Byzantium, 1261-1453 (New York: Cambridge University Press, 1972), 346; Malgorzata Dabrowska, „Bassilissa ergo gaude... Cleopa Malatesta’s Byzantine CV,“ Byzantinoslavica 63 (2005), 217-224; Diana G. Wright, The Brides of 1420: Men looking at Women's Bodies, in Questions of Gender in Byzantine Society, ed. Bronwen Neil, Lynda Garland (Farnham-Burlington: Ashgate), 133-152.

${ }_{5}^{5}$ Mihai D. Sturdza, Grandes familles de Grèce; d'Albanie et de Constantinople, Dictionnaire historique et généalogique (Paris: M.-D. Sturdza, 1983), 540. M. Dabrowska, "Sophia de Montferrat," 181.
} 
Orthodox and Catholic churches ${ }^{6}$ and secured permission from Pope Martin V (r. 1417-1431) to find Catholic wives for his two elder sons. ${ }^{7}$ The Pope, hoping to finally heal the breach that had troubled the church for four centuries, decided to allow the Byzantine princes to marry Latin princesses, provided that the latter would maintain their confessions and keep priests of their own rite at their courts. ${ }^{8}$ Papal permission in hand, Manuel's ambassador, Michael Eudaimonoioannes, could approach Italian rulers regarding eligible partners for the imperial heirs. Blood ties and political connections of long standing with the Palaiologans (and possibly the recommendation of the Pope himself ${ }^{\text {? }}$ ) led to Michael's choosing a princess from the House of Montferrat to marry the future John VIII. ${ }^{10}$

6 Raymond-Joseph Loenertz, "Les dominicains byzantins Théodore et André Chrysobergès et les négotiations pour l'union des Eglises grecque et latine de 1450 à 1430," Archivum Fratrum Praedicatorum 9 (1939): 5-61, 31.

7 Annales ecclesiastici, ad anno 1418, XVIII, Odorico Raynaldus (ed.), Roma 1659, n. 17. Vitalien Laurent (ed.), Les „Mémoires” de Sylvestre Syropoulos sur le concile de Florence (14381439) (further only Syropoulos), (Paris: Publications de l'Institut français d'études byzantines, 1971), 106, 6.

8 Epistolae Pontificiae ad Concilium Florentinum Spectantes (...), Georg Hofmann (ed.), (Rome: Pontificium Institutum Orientalium Studiorum, 1940-1946), doc. 2. Spyridon

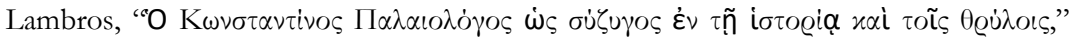
[Constantine Palaiologos as husband in history and in legends], Neos Ellenomnemon 4 (1907): 417-466, 430. Charles Diehl, Figures byzantines, vol. II (Paris: Librairie Armand Colin, 1924), 273-275. Also see Malgorzata Dabrowska, "Is there any Room on the Bosporus for a Latin Lady? Byzantinoslavica 66 (2008): 229-239.

${ }^{9}$ Steven Runciman indicates that the marriage of John and Sophia was an attempt on Manuel's part to achieve better relations with Genoa. Steven Runciman, "The Marriages of the Sons of Manuel II," Rivista di Studi Bizantini e Slavi 1 (1981) (=Miscellanea Agostino Pertussi, vol. 1): 278-280, see especially 276f. Dr. Dabrowska opposes this explanation by arguing that Sophia's father had already lost his power over Genoa by 1413. She suggests that the Pope recommended Sophia due to his new alliance with the House of Montferrat which traditionally connected with the imperial (Ghibelline) party. Such a union would present a challenge to the Viscontis, who at that time were considered a threat to the papal state. The main advantage for the Byzantines was the full support of the Pope himself. For further details, see M. Dabrowska, "Sophia de Montferrat," $181 \mathrm{f}$.

10 The connection dates back to the rule of Manuel I, who made an alliance with the marquisate following the disastrous Battle of Myriokephalon (1176) in order to break the coalition of the Turks and the German emperor, Friedrich I Barbarossa. For a more detailed account of this connection, see M. Dabrowska, "Sophia de Montferrat," $179 \mathrm{f}$. For the political context of Sophia's marriage, see S. Runciman, The marriages, 276278. 
In 1420, Sophia's younger brother and guardian, John James, signed a marriage contract with Eudaimonoiannes. Soon afterwards, Sophia sailed to Byzantium along with her future sister-in-law, Kleope Malatesta di Pesaro di Rimini, ${ }^{11}$ who was destined to marry Manuel's second son, Theodore. The two ladies boarded a Venetian galley in Chioggia and arrived in the Byzantine capital in November of the same year. ${ }^{12}$ Several months elapsed before Sophia's wedding took place, possibly due to an initial unwillingness on the part of the bridegroom to go through with the arrangement. Ultimately, John bowed to the will of his father and married Sophia. Considering that he would finally be crowned and confirmed in his position as co-emperor, this marriage may have provided the necessary incentive. The ceremony, conducted by Patriarch Joseph, took place in Hagia Sophia on January 19, 1421.13 The coronation of the young imperial couple, during which the Patriarch pronounced Sophia 'empress of the Romaioi,' 14 followed the wedding ceremony.

The marriage was not a happy one - if it was a marriage at all. John, himself an attractive man who had inherited the handsome features of his father, avoided his wife from the beginning and allegedly never consummated the union. ${ }^{15} \mathrm{He}$ soon found solace in the arms of his mistresses ${ }^{16}$ and probably welcomed any excuse to be absent from the

11 For details, see PLP, n. 21385.

12 Georgios Sphrantzes, Cronaca (Corpus Fontium Historiae Byzantinae = CFHB, 29), (further only Sphrantzes), ed. Riccardo Maisano (Rome: Accademia Nazionale dei Lincei, 1990), 14.

13 Die byzantinische Kleinchroniken (Chronica byzantina breviora), I-III, (CFHB, 12/1-3), (further only Schreiner, Kleinchroniken), ed. Peter Schreiner (Vienna: Verlag der Österreichischen Akademie der Wissenschaften, 1975-1979), II, 617, n. 65. Sphrantzes, 14. Doukas explains the delay by pointing out that "when the emperor [John] first laid eyes on her, he wanted to send her back to Italy to her father's home, but because of his affection for his father, Emperor Manuel, he could not bring himself to do so." Mihail Doukas, Istoria Turco-Bizantina [Turkish-Byzantine History], 1341-1462 (further only Doukas) (Scriptores byzantini, I), ed. Vasile Grecu (Bucharest: Editura Academiei Republicii Populare Române, 1958), 137 (XX, 6). Doukas, Decline and Fall of Byzantium to the Ottoman Turks by Doukas (further only Magoulias, Doukas), transl. Harry J. Magoulias (Detroit: Wayne State University Press, 1975), 113, (XX, 6).

${ }_{14}$ Schreiner, Kleinchroniken, I, 98, n. 48.

15 Doukas, 137 (XX, 6).

16 Makarios Melissenos, Cronica 1258-1481, in Georgios Sphrantzes, Memorii 14011477, ed. Vasile Grecu (Bucharest: Editura Academiei Republicii Socialiste România, 1966), 150-590. Pseudo Sphrantzes mentions: "Lady Sophia returned to her homeland 
capital. ${ }^{17}$ A contemporary historian, Laonikos Chalkokondyles noted that Sophia "was pleasant in manner but not attractive in the face. (...) he [John] did not live with her; he became hostile and disagreeable to her for a time, and the wife of the emperor noticed that her husband was behaving disagreeably and that she was very hateful to her husband."18

While Sophia may have received some comfort from the ladies and servants who had come with her from Italy and from her spiritual father and confessor, the Catholic friar William of Pera, her unhappy marriage and lack of integration into the Byzantine court gradually became unbearable. Modern psychological studies reveal that people with disabilities which severely impact their lives often develop depression, psychological crises, and related disorders. ${ }^{19}$ While the sources reveal nothing specific about Sophia's feelings and mental health, it is very likely that she was no exception.

The empress's position grew even more precarious after her fatherin-law and main supporter in Constantinople, Manuel II, died in July 1425. Instead of patiently awaiting the end of her own life, semiimprisoned in her chambers, Sophia decided to leave. On an August day in 1426, giving the excuse hat she wished to enjoy the gardens on the coast of the Bosporus, she left the city with her Italian ladies-inwaiting and some young men from her homeland. In the late afternoon, her Genoese accomplices boarded a bireme and sailed to meet the empress and her company. Sophia accepted their invitation to visit Pera (Galata), crossed to the Asian coast and was heartily welcomed by the inhabitants of the city. Soon afterwards, "as the north wind began to

as our emperor has shown no affection for her, but preferred other women, as Lady Sophia had not been endowed with beauty by nature." (Transl.) Marios Philippides, The Fall of the Byzantine Empire: A Chronicle by George Sphrantzes, 1401-1477 (Amherst: The University of Masachussetts Press, 1980), 139, n. 4.

${ }_{17}$ In 1423, John VIII undertook a mission to Hungary to obtain military aid against the Turks from Sigismund of Luxembourg. For details, see Sphrantzes, 24 (XII, 3). Kenneth M. Setton, The Papacy and the Levant (1204-1571), I-III, (Philadelphia: The American Philosophical Society, 1976-1981), II, 25.

18 Laonikos Chalkokondyles, Laonici Chalcocondylae Historiarum Demonstrationes, ed. Eugenius Darkó, I-II (Budapest, 1922), I, 192. Transl. D. Wright, The Brides of 1420, 136.

19 Clemens Hausmann, Psychologie und Kommunikation für Pflegeberufe: Ein Handbuch für Ausbildung und Praxis (Vienna: Facultas, 2014), 176. 
blow," the empress boarded a Genoese ship apparently belonging to her relatives, the Spinolas, and sailed to Italy. ${ }^{20}$

According to the historian Doukas, Sophia took nothing with her except for the imperial crown. She allegedly said concerning the jewel, "This is the testimony that I was and am Empress of the Romans. I care not for precious treasure." 21 This declaration could be understood in the sense that her husband was not merely informed of her plans to leave but had even offered his wife financial compensation so that she would not return to her home country destitute. ${ }^{22}$ Her parting words suggest that if such an offer had been made, she generously refused it, deciding to keep only her crown as proof of her coronation and as a souvenir of the years she had spent in Byzantium.

After landing in Genoa, the empress passed her first days in Italy as a guest of the Spinola family ${ }^{23}$ before being festively welcomed by her brother John James and the nobles of Ferrara. Nevertheless, as a married woman who had left her husband, her position in society was awkward. Having already faced so much humiliation, Sophia chose to spend her remaining days in a peaceful environment where beauty was of no consequence and where she could conveniently cover her face with a thick black veil. Sophia entered an unknown Catholic convent where she presumably lived a pious life for another eight years. She died on August 21, 1434, ${ }^{24}$ at the age of about forty.

20 Doukas, 139 (XX, 6). (Transl.) Magoulias, Doukas, 113-114 (XX, 6). Sphrantzes correctly places the return of the empress to Italy to August 1426 (Sphrantzes, 30 (XIV, 2)). Doukas states that on learning of Sophia's departure for Galata (Pera), the Byzantine palace officials proposed to storm the latter city and bring her back. He also claims that Emperor Manuel, who was resolved to force his son no further, prevented their intervention and that John openly "approved of what had taken place." Doukas clearly confused the years, not realizing that at the time of Sophia's flight, Manuel was already dead. Nevertheless, his report suggests that the young emperor fully supported the 'escape' of his wife and may even have had a hand in it, which would, perhaps, explain the somewhat mysterious words uttered by the empress before boarding the Genoese ship.

${ }^{21}$ Doukas, 139 (XX, 6). (Transl.) Magoulias, Doukas, 114 (XX, 6).

22 M. Dabrowska, History of One Face, 189.

23 Annales Genuenses, ed. Georgius J. Stella, in Rerum Italicarum Scriptores, vol. 17/2, ed. Giovanna Petti Balbi (Bologna, 1975), 302. M. Dabrowska, Sophia de Montferrat, 189.

${ }^{24}$ Based on the admittedly inaccurate account of Sturdza (M. Sturdza, Grandes familles de Grèce; d'Albanie et de Constantinople, 540), Dr. Dabrowska claims that Sophia died in Trino near Casale in 1437. M. Dabrowska, "Sophia de Montferrat," 190. 


\section{The heretic}

Lack of beauty was not Sophia's only disadvantage. The Pope insisted that the bride of the Orthodox heir to the throne remain Catholic, and the written permission provided by the father of the groom, Manuel II, would indicate that she did so. For the only time in the history of the empire, a Catholic princess was wed to the emperor - to the consternation of many. Symeon, the archbishop of Thessalonike, considered her marriage to Emperor John VIII a misuse of oikonomia, a concession that brought about divine wrath as manifested by the Ottoman siege of Constantinople in 1422, the ensuing famine, and further trouble with the Republic of Genoa. In reality, the Ottoman ruler attacked Byzantium because the emperor supported the sultan's brother in his rebellion against the sultan. ${ }^{25}$ About this troubled period, Symeon wrote:

Now this [siege and famine], I think, was a disciplinary chastisement inflicted on it [Constantinople] by God for other reasons, but also to teach us not to have communion of any kind at all with those who are excommunicated by the Church. For you know what things happened at that time: how that woman of Italian race, who had neither submitted to the Church nor become its daughter, nor publicly recognized the Church's hierarchs as her fathers, nor confessed the Symbol of Faith of the Fathers in the right form in which it was drawn up, was simply received and proclaimed Empress of the Orthodox together with the faithful Emperor in violation of the sacred canons. Now this was something which many persons scrupulous about divine matters found hard to stomach at the time; they testified by this token that an ordeal would follow; and that in fact is how it turned out, for after a while the Emperors had a trying experience thrust upon them by the

\footnotetext{
${ }^{25}$ For details, see Elizabeth Malamut, "La figure de l'ambassadeur byzantin auprès des Ottomans dans la première moitié du XVe siècle," in La figure de l'ambassadeur entre mondes éloignés: Ambassadeurs, envoyés officiels et représentations diplomatiques entre Orient islamique, Occident latin et Orient chrétien XIe - XVIe siècle, ed. Nicolas Drocourt (Rennes: Presses Universitaires de Rennes, 2015), 79-95, see 85f.
} 
Italians. Everyone knows what initiatives detrimental to the Roman interests the men from Genoa, as mentioned above, and others with them were up to at that time. ${ }^{26}$

In his criticism of the empress, Symeon reveals the central aspects of the conversion ceremony required of a foreign, non-Orthodox princess. She had to recognize the hierarchs, the Patriarch, and the Byzantine clergy as her fathers and recite the confession of faith in the proper form. Following these solemn ceremonies, an empress was expected to attend Orthodox services along with her husband and, ideally, support Orthodoxy in the various controversies of the church and possibly through pious donations. As a member of another church (one that was, moreover, considered schismatic by adherents of Orthodoxy), Sophia could not possibly fulfill her representative duties in this respect.

Obviously, Sophia's position was highly unusual, especially as other late-Byzantine empresses of foreign origin (there were altogether eleven ${ }^{27}$ ) converted to Orthodoxy, and most of them appear in the Synodikon of Orthodoxy, which is read every year to commemorate pious empresses who remained faithful to the Orthodox creed. The Pope's desire to safeguard Sophia's salvation forced the princess into an impasse at the imperial court. Even if she had wished to participate in the ceremonies of the Byzantine church, she would not have been able to partake of the Holy Communion, a circumstance which would have meant continual degradation in front of her people. On the other hand, by converting to Orthodoxy, Sophia would have exposed herself to the condemnation of the Pope and would have jeopardized her possible return to the West, apparently a bridge which she did not dare to burn.

${ }^{26}$ David Balfour (ed.), Politico-Historical Works of Symeon, Archbishop of Thessalonica. Critical Greek Text with Introduction and Commentary (Wiener byzantinische Studien, vol. 13), (Vienna: Verlag der Österrechischen Akademie der Wissenschaften, 1979), 147. D. M. Nicol, "Mixed Marriages in Byzantium in the Thirteenth Century," in Studies in Church History vol. 1, ed. C. W. Dugmore, Charles Duggan (London-Edinburgh, 1964), 160_ 172.

27 The foreign brides of late Byzantine emperors included Anna of Hungary (r. 12721281), Eirene (Yolanda) of Montferrat (1284-1317), Maria (Rita) of Armenia (12941333), Eirene (Adelheid von Braunschweig-Grubenhagen) (1318-1324), Anna (Johanna) of Savoy (1326-ca. 1365), Maria (Keraca) of Bulgaria (1376-after 1400), Eirene Gattilusio (1397-1440), Helene Dragaš (1392-1450), Anna of Moscow (14141417), Sophia of Montferrat (1420-1426), Maria of Trebizond (1427-1439). 
John, also, may have defended her right to maintain her confession in order to maintain a possible ground for divorce. The fact that Sophia remained Catholic made her a heretic in the eyes of her subjects and undermined her authority and popularity within the empire.

\section{The importance of being - beautiful}

The importance that Byzantines attached to female beauty permeates Greek texts from ancient times until the very end of the Byzantine Empire. Examples include Leda and Medeia, whose beauty gave no sleep to the ruler of the gods as well as ancient goddesses like Aphrodite, Artemis, and Hera, whose loveliness was legendary. Moving towards historical times, we encounter Helen (a woman whose exquisite face became proverbial and was the alleged cause of the Trojan War) and the late antique and early medieval martyrs such as St. Thekla and St. Catherine, whose seductive bodies were destroyed in a barbarous manner at the command of their rejected suitors. In the middle Byzantine period, the sources describe the alluring heroines of medieval Byzantine epics: Rhodante, Kallithea and Hysmine as well as the women of the Digenis Akrites epos. As for the empresses themselves, Maria of Amnia, Irene the Athenian, and Theodora, the wife of Emperor Theophilos were apparently chosen in beauty contests while the appearance of others, including Theophano, Maria of Alania and Maria of Trebizond, was extolled by their contemporaries.

Confronted with such overwhelming expectations of (facial) beauty, it is clear that a woman who had none to start with was in an unenviable position. The truth of this is well illustrated by the fate of the Montferrat princess, whose disfigured face apparently played a crucial role in her failed entrance into the Byzantine environment. The historian Doukas seems to have known the empress in person (as Dr. Dabrowska points out) ${ }^{28}$ and possibly facilitated the connection between the empress and the Genoese settlement in Pera. He was therefore well placed to pen a detailed description, unique in the late Byzantine sources, of Sophia's appearance:

The young woman was extremely well proportioned in body. Her neck was shapely, her hair blondish with braids

${ }^{28}$ For the argument, see M. Dabrowska, "Sophia de Montferrat," $188 \mathrm{f}$. 
flowing down to her ankles like glimmering golden streams. Her shoulders were broad and her arms, bosom, and hands well proportioned. Her fingers were transparent. She was tall in stature and stood very straight - but her face and lips and the malformation of her nose, eyes, and eyebrows presented a most revolting composition. ${ }^{29}$

As Doukas had no reason to be biased against the empress, his testimony must reflect truth, an assumption that is supported by the fact that John VIII, himself a poet, avoided his wife from the beginning. Indeed, the emperor showed no interest whatsoever in the person behind the distorted face even though Sophia must have been exposed to classical art and learning, both of which were widespread in fifteenth-century Italy, and her mind could possibly have offset the deficiencies of her face. ${ }^{30}$ The story of the fifteenth-century imperial couple reveals that even though despising one own's beauty was deemed a praiseworthy behavior in saints and nuns, overlooking the (unflattering) appearance of one's spouse was not expected of a husband in late Palaiologan Byzantium.

Even though Sophia's marred face did not in and of itself prevent the empress from taking part in a variety of physical or mental activities, it had an enormous impact on her life. Merriam Webster Dictionary defines 'handicap' as "a physical or mental condition that may limit what a person can do." 31 Pondering Sophia's life, her appearance directly prevented her from entering her role as wife, mother and empress. This limitation is reflected by Clemens Hausmann, who in his study, Psychologie und Kommunikation für Pflegeberufe, writes: "A handicap is more than just a personal problem caused by disease or accident, which should be treated by specialists. A handicap also has consequences on a personal and social level and requires social action and communal responsibility to enable the participation of the handicapped person in all areas of social life." 32 Nowadays in an age of plastic surgery and couple's therapy, a disfigured face need not become a true handicap,

\footnotetext{
${ }^{29}$ Doukas, 137 (XX, 6). (Transl.) Magoulias, Doukas, 113 (XX, 6).

${ }^{30}$ M. Dabrowska, "Sophia de Montferrat," 183.

31 Merriam Webster at:

http://www.learnersdictionary.com/definition/handicap (retrieved September 19, 2017), the italics in the quotation were added to highlight my point.

32 C. Hausmann, Psychologie und Kommunikation, $175 \mathrm{f}$.
} 
but fifteenth century medicine was not yet sophisticated enough to 'mend' the face and provide marital counselling. As John's aversion towards his wife proved irremediable, the empress lost the chance to experience companionship with her husband as well as the opportunity to conceive an imperial heir. While motherhood has often been a consolation to the unloved wife, Sophia was denied not only the joy of holding her own child but also the confirmation of her position at the Byzantine court that an heir could have afforded her.

At yet another level, Sophia must also have experienced difficulty in entering her imperial role. Naturally, her disability would have caused her serious problems even if she had been born a commoner. She might have entered a monastery at an early age or languished at the edge of society, scorned and humiliated. As an empress, however, her situation was even worse. While she did not need to fear direct physical or verbal abuse, her position demanded that she participate in the audiences and ceremonies of the court where she would have to reveal her disfigured face and watch her subjects and courtiers turn away at the sight. While the presence of other late Byzantine empresses at official audiences and counsels is frequently noted by chroniclers, such evidence is missing for Sophia. The sources are nevertheless explicit in that her husband, embarrassed of his wife, caused the empress to spend her time in a remote part of the palace. ${ }^{33}$

In addition to the universal expectation of royal beauty, the stigma of disfigurement was deeply rooted in the Byzantine culture. Early emperors had their opponents blinded or had their noses cut off. The case of Irene (r. 797-802), who had her own son, Constantine VI (r. 790-797), deprived of sight (797) in order to isolate him from power, is a well-known example. ${ }^{34}$ The unpopular Empress Martina had her tongue cut out; her son's nose was slit. ${ }^{35}$ Michael V (r. 1041-1042) was blinded by the empresses Zoe (r. 1028-1050) (whom he had schemed to

\footnotetext{
33 Doukas, 137 (XX, 6).

${ }^{34}$ For details on Eirene's life and further sources, see ODB II, 1008f. Theophanis Chronographia, ed. Carl de Boor, 2 vols. (Leipzig: B.G. Teubner, 1883), reprint. (Hildesheim-New York, 1980), I, 472. Judith Herrin, Women in Purple (London: Phoenix Press, 2002) (2nd ed.), see 51-129, for blinding of her son, see 99. Judith Herrin, Blinding in Byzantium, in Polypleuros Nous. Festschrift Peter Schreiner (Byzantinisches Archiv, vol. 19), ed. Georgios Makris, Cordula Scholz (Munich-Leipzig: Saur, 2000), 56-68.

${ }^{35}$ For Martina, see ODB II, 1307f., for her son Heraklonas, see ibid. 918.
} 
remove from power) and Theodora (r. 1042-1056) upon their reinauguration. ${ }^{36}$ Often the punishment of "sinners," especially men and women caught in adultery, included having their faces disfigured. While men thus stigmatized could still acceed to the throne, their position was precarious. In late Byzantium, for example, the fact that Andronikos IV (r. 1376-1379) and his son John VII (r. 1390) had been partially blinded as punishment for Andronikos's rebellion against his father certainly impacted their subjects' perception of them and possibly contributed to the succession of the parallel imperial line of Manuel II to the Byzantine throne. ${ }^{37}$ Beside losing their sight, tongue, or nose, the Byzantines were sometimes punished by loss of hair through tonsure. . Even though Sophia's face was not maimed as punishment for (sexual) sin or political trespass, the mere fact of its disfigurement must have evoked negative connotations in her subjects.

\section{The divorce that did not materialize}

The significance of Sophia's disability becomes evident when we consider her case against the only other attempt of a late Byzantine emperor to have his marriage dissolved. In the second half of the thirteenth century, Michael VIII (r. 1259-1282), the founder of the Palaiologan dynasty contemplated divorcing his wife, Theodora Palaiologina (d. 1303). His reasons did not only include the charms of the daughter of Holy Roman Emperor Frederick II (r. 1212-1250), Constance von Hohenstaufen (known in Byzantium as Empress Anna) (d. 1307), but mainly the political situation of the empire. In 1204, the soldiers of the Fourth Crusade had seized Constantinople and most of its territories. After re-conquering the ancient capital in 1261, Michael was well aware that Western rulers would attempt to recover the Greek territory they had lost, and he hoped that by marrying Anna, he would be able to acquire powerful allies in the West to counter an attack when it came. On learning of her husband's plans, Theodora, by then the mother of no fewer than five children, requested aid from the patriarch,

\footnotetext{
36 ODB II, 1366. Imperatori di Bisanzio (Cronografia), (further only Psellus), Salvatore Impellizzeri, ed. Carlo Vicenzo, trans. S. Ronchey (Milan: Mondadori 1997),(3rd ed.), (book five). Michael Psellus, Fourteen Byzantine Rulers: The Chronographia of Michael Psellus, E.R.A. Sewter, (London - New York: Penguin Books, 1966) (1 ${ }^{\text {st }}$ published 1953), 144 151.

${ }^{37}$ Doukas, 71 (XII, 2).
} 
who subsequently threatened the emperor with excommunication and forced Michael to abandon the divorce. ${ }^{38}$

Explaining why there was no reason to repudiate Theodora, the contemporary historian, George Pachymeres, claimed that she "was a good woman, descended from a great imperial line. She could not be reproached either in respect to her birth, chastity in the midst of immoral behavior, lack of love towards her husband [Michael VIII] or ability to rule with him." 39 Even though Sophia theoretically fulfilled at least five of these six "requirements," the differences between her and Theodora become quickly apparent. Though Theodora was perhaps no great beauty, her appearance must have been deemed acceptable as no record to the contrary exists. She was also Byzantine born, mother of the imperial heir (and his siblings), and secure in her imperial role. Theodora's case reveals the qualities which enabled an empress to maintain her position contrary to the wishes of her spouse. If an empress could produce a successor to the throne, fulfill her imperial duties in regard to the church and the court, and maintain a strong link with Orthodoxy, her husband could not easily dismiss her.

\section{Conclusion}

Despite her noble origin, papal permission to marry an Orthodox prince and support of Emperor Manuel II, Sophia of Montferrat failed to integrate into the Byzantine society at several different levels. Sophia's disfigured face prevented her from securing the love of her husband and entering into the role of wife and mother, while her holding on to the Catholic confession prevented her from being perceived as pious and Orthodox empress leading to her rejection by the representatives of the church and even her subjects. Her case in this respect has no precedence, which makes Sophia, the crowned empress and angousta of the Romans the ultimate 'other' empress of Byzantium. At the same time, her fate reveals valuable information about the position of an empress in (late) Byzantium. Since the emperor held the

\footnotetext{
38 George Pachymeres, Relations historiques (CFHB, 24/I-IV) (further only Pachymeres), Albert Failler (ed. I-IV, transl. III-IV), Vitalien Laurent (transl. I-II), (Paris: Société d'edition des belles lettres, 1984), vol. I, 245ff. (III, 7-8).

Nikephoros Gregoras, Byzantina Historia, I-II, (CSHB) (further only Gregoras), ed. Ludwig Schopen (Bonn 1829, 1830); I, 93.

39 Pachymeres I, 245 (III, 7-8).
} 
power and performed all important political, ecclesiastical and military duties, one might conclude that any well-connected woman could ascend the throne. Sophia's fate qualifies 'any woman' in the sense that an empress had to possess enough beauty to secure the affection of her husband and was required to adhere to Orthodoxy in order to secure the approval of the clergy and the people. A woman unable to fulfill these two conditions could not long remain an empress in Byzantium.

\section{References}

\section{Primary sources}

Annales ecclesiastici, ad anno 1418, XVIII. Odorico Raynaldus ed. Roma 1659.

Annales Genuenses. Georgius J. Stella, ed. In Rerum Italicarum Scriptores, vol. 17/2, ed. Giovanna Petti Balbi. Bologna, 1975.

Chalkokondyles, Laonikos. Laonici Chalcocondylae Historiarum

Demonstrationes, ed. Eugenius Darkó, I-II. Bucharest: Editura

Academiei Republicii Populare Române, 1922.

Doukas, Mihail. Istoria Turco-Bizantina [Turkish-Byzantine History],

1341-1462 (Scriptores byzantini, I), ed. Vasile Grecu. Bucharest:

Editura Academiei Republicii Populare Române, 1958.

Doukas. Decline and Fall of Byzantium to the Ottoman Turks by Doukas, transl. Harry J. Magoulias. Detroit: Wayne State University Press, 1975.

Epistolae Pontificiae ad Concilium Florentinum Spectantes, ed. Hofmann, Georg. Rome: Pontificium Institutum Orientalium Studiorum, 1940-1946.

Gregoras, Nikephoros. Byzantina Historia, I-II, (CSHB), ed. Ludwig Schopen (Bonn 1829, 1830).

Melissenos, Makarios. Cronica 1258-1481. In Georgios Sphrantzes, Memorii 1401-1477 (Scriptores Byzantini, vol. 1), ed. Vasile Grecu. Bucharest: Editura Academiei Republicii Populare Române, 1966. Pachymeres, George. Relations historiques, I-V (Corpus Fontium Historiae Byzantinae $=$ CFHB, 24/I-V). Edited and translated by Albert Failler and Vitalien Laurent. Paris: Société d'edition des belles lettres, 1984-2000. 
Philippides, Marios. The Fall of the Byzantine Empire: A Chronicle by George Sphrantzes, 1401-1477. Amherst: The University of Masachussetts Press, 1980.

Psellus, Michael. Imperatori di Bisanzio (Cronografia), ed. Salvatore Impellizzeri, Carlo Vicenzo, transl. Silvia Ronchey. Milan: Mondadori, 1997 (3rd ed.). . Fourteen Byzantine Rulers: The Chronographia of Michael Psellus, transl. E.R.A. Sewter. London-New York: Penguin Classics, 1966 (1 ${ }^{\text {st }}$ published 1953).

Schreiner, Peter (ed). Die byzantinische Kleinchroniken (Chronica byzantina breviora), I-III, (CFHB, 12/I-III ). Vienna: Verlag der Österreichischen Akademie der Wissenschaften, 1975-1979. Sphrantzes, Georgios. Cronaca (CFHB, 29), ed. Riccardo Maisano.

Rome: Accademia Nazionale dei Lincei, 1990.

Syropoulos, Sylvestre. Les „Mémoires“ de Sylvestre Syropoulos sur le concile de Florence (1438-1439), ed. Vitalien Laurent. Paris: Publications de l'Institut français d'études byzantines, 1971.

Theophanis Chronographia: Theophanis vitas, Anastasii Bibliothecarii historiam tripertitam, dissertationem de codicibus operis Theophanei, Indices continens. Carl de Boor (ed.), 2 vols. Leipzig: B.G. Teubner 1883, reprint. Hildesheim-New York, 1980.

\section{Secondary sources}

Balfour, David, ed. Politico-Historical Works of Symeon, Archbishop of Thessalonica. Critical Greek. Text with Introduction and Commentary.

Vienna: Verlag der Österrechischen Akademie der Wissenschaften, 1979.

Dabrowska, Malgorzata. "Bassilissa ergo gaude.” Byzantinoslavica 63 (2005): 217-224. . "Sophia de Montferrat or the History of One Face." Acta Universitatis Lodriensis, Folia historica 56 (1996): 177-194.

Diehl, Charles. Figures byzantines, Vol. I-II. Paris: Librairie Armand Colin, 1924.

Hausmann, Clemens. Psychologie und Kommunikation für Pflegeberufe: Ein Handbuch für Ausbildung und Praxis. Vienna: Facultas, 2014.

Hill, Barbara. Imperial Women in Byzantium 1025-1204: Power, Patronage and Ideology. London: Routledge, 1999. 
Herrin, Judith. "Blinding in Byzantium.” In Polypleuros Nous. Festschrift Peter Schreiner (Byzantinisches Archiv, vol. 19), ed. Georgios Makris, Cordula Scholz. Munich-Leipzig: Saur, 2000.

Herrin, Judith. Women in Purple. London: Phoenix Press, 2002 (2nd ed.)

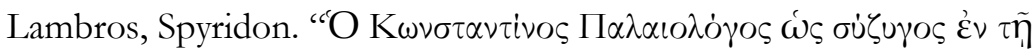

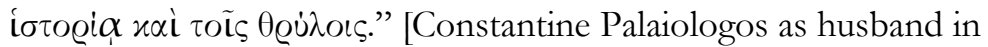
history and in legends], Neos Ellenomnemon 4 (1907): 417-466.

Loenertz, Raymond-Joseph. "Les dominicains byzantins Théodore et André Chrysobergès et les négotiations pour l'union des Eglises grecque et latine de 1450 à 1430." Archivum Fratrum Praedicatorum 9 (1939): 5-61.

Malamut, Elisabeth. "La figure de l'ambassadeur byzantin auprès des Ottomans dans la première moitié du XVe siècle." In La figure de l'ambassadeur entre mondes éloignés: Ambassadeurs, envoyés officiels et représentations diplomatiques entre Orient islamique, Occident latin et Orient chrétien XIe-XVIe siècle, ed. Nicolas Drocourt, 79-95. Rennes: Presses Universitaires de Rennes, 2015.

Melichar, Petra."Female incompetence, misogyny and xenophobia or a faulty marital policy on the part of the late Byzantine emperors?." Byzantinoslavica 74 (2016): 61-74.

Nicol, Donald M. "Mixed Marriages in Byzantium in the Thirteenth Century." Studies in Church History 1 (1964): 160-172. . The Last Centuries of Byrantium, 1261-1453. New York: Cambridge University Press, 1972.

Runciman, Steven. "The Marriages of the Sons of Manuel II." Rivista di Studi Bizantini e Slavi 1 (1981) (=Miscellanea Agostino Pertussi, vol. 1): 273-282.

Setton, Kenneth M. The Papacy and the Levant (1204-1571), I-III. Philadelphia: The American Philosophical Society, 1976-1981. Sturdza, Mihai D. Grandes familles de Grèce; d'Albanie et de Constantinople, Dictionnaire historique et généalogique. Paris: M.-D. Sturdza, 1983.

Trapp, Erich, Rainer Walther, and Hans-Veit Beyer et al. Prosopographisches Lexikon der Palaiologenzeit. Vol. 1-12. Vienna: Verlag der Österreichischen Akademie der Wissenschaften, 1976-96.

Wright, Diana G. "Brides of 1420: Men looking at Women's Bodies." In Questions of Gender in Byzantine Society, ed. Bronwen Neil, Lynda Garland. Farnham-Burlington: Ashton, 2013. 